\title{
Vocal Fold Regeneration: Current Review
}

\author{
Choung-Soo Kim \\ Department of Otolaryngology-Head and Neck Surgery, College of Medicine, The Catholic University of Korea, \\ Daejeon St. Mary's Hospital, Daejeon, Korea
}

성대 재생: 현시점에서의 고찰

김 청 수

가톨릭대학교 의과대학 대전성모병원 이비인후과학교실

\author{
Received April 6, 2018 \\ Revised May 4, 2018 \\ Accepted May 15, 2018 \\ Address for correspondence \\ Choung-Soo Kim, MD \\ Department of Otolaryngology- \\ Head and Neck Surgery, \\ College of Medicine, \\ The Catholic University of Korea, \\ Daejeon St. Mary's Hospital, \\ 64 Daeheung-ro, Jung-gu, \\ Daejeon 34943, Korea \\ Tel $+82-42-220-9580$ \\ Fax $+82-42-221-9580$ \\ E-mail drchoung@catholic.ac.kr
}

The extracellular matrix (ECM) of the vocal folds cannot be replaced after severe injury, but heal as scars. Scarred vocal folds cause voice problems. Many treatments have been attempted for vocal fold scarring, but their effectiveness is limited because the ECM composition does not normalize. Therefore, until now the prevention of scar formation has been important. In the field of regenerative medicine, cell therapies such as stem cell transplantation, and the implantation of several types of growth factors with or without scaffolds have been used. In this article, we reviewed the published research related to vocal fold regeneration and tried to think about the limitations of current studies and the future direction of treatment.

Korean J Otorhinolaryngol-Head Neck Surg 2018;61(6):275-80

Key Words Regenerative medicine $\cdot$ Scaffold $\cdot$ Stem cell $\cdot$ Tissue engineering $\cdot$ Vocal fold.

\section{서 론}

전자 문서, 메일, SNS가 빠르게 보급되면서 음성을 통한 의 사소통은 줄어들었지만, 음성은 여전히 의사소통의 중요한 수단이며, 또 개개인의 특성을 나타내는 지문과 같은 역할을 한다. 최근 사회적으로 서비스 직종이 늘어나고, 삶의 질이 향 상되면서 음성에 대한 인식이 바뀌고 있으며, 또 보다 좋은 음 성에 대한 요구가 늘어나고 있다. 과거 성대 질환의 치료는 병 변의 완전한 제거를 목적으로 하였으나, 현재는 병변의 제거 뿐 아니라 성대의 구조를 보존하는데도 중점을 주고 있다.

성대의 세포외간질(extracellular matrix)은 독특한 구조로 이루어져 있으며, 손상이 일어나면 반흔 조직으로 치유되기 때문에 기능에 제한을 가지게 된다. 미세 수술과 정교한 기

This is an Open Access article distributed under the terms of the Creative Commons Attribution Non-Commercial License (http://creativecommons.org/licenses/by-nc/4.0) which permits unrestricted non-commercial use, distribution, and reproduction in any medium, provided the original work is properly cited.
구, 그리고 레이저 등의 사용으로 손상 부위를 최소화하였지 만 반흔 생성을 피하기는 어렵다. 형성된 반흔 조직을 치료하 기 위해서 다양한 방법이 시도되고 있다. 그러나 세포외간질 의 조성이 정상화 되지 않기 때문에 한계가 있다. 따라서, 형성 된 성대 반흔 조직을 치료하는 것보다 반흔 조직의 생성을 예방하는 것이 더욱 중요하다고 할 수 있다. ${ }^{1)}$ 본 연구에서는 성대 재생에서 최근까지 보고된 국내외의 연구 결과를 정리 하고, 앞으로의 연구 방향에 대해 생각하는 기회를 가지고자 한다.

\section{성대의 기본구조 및 반흔 조직의 특징}

성대는 상피(epithelium), 고유층(lamina propria), 그리고 갑상피열근(thyroarytenoid muscle)으로 구성된다. 상피층 은 성대의 표면으로 성대의 깊은 구조를 보호한다. 고유층은 상피층과 갑상피열근 사이에 콜라겐(collagen)과 탄성섬유 
(elastic fiber)가 풍부한 유연한 조직으로 상층(superficial lamina propria), 중층(intermediate lamina propria) 그리고 심층(deep lamina propria)으로 구분할 수 있으며, 콜라겐과 탄성섬유가 상대적으로 적은 상층이 조금 더 단단한 중층과 심층 위에서 상대적으로 자유롭게 움직이며, 성대의 진동에 중요한 역할을 한다. 갑상피열근은 고유층의 심층 아래에 위 치한다. 성대의 진동은, 고유층의 상층과 그리고 그 이하 층 들의 진동특성 차이, 그리고 성문의 모양과 그에 따른 공기압 의 차이로 인해서 발생한다. 음성외상(phonotrauma)으로 유 발되는 성대의 부종 및 염증과 같은 약한 손상은 대식세포 (macrophage) 또는 근섬유아세포(myofibroblast) 등에 의해 치료될 수 있으나, 성대의 직접 손상이 일어나는 경우 반흔과 같은 영구적인 변형이 일어난다. ${ }^{23)}$ 성대의 반흔은 고유층의 강 성(stiffness) 및 점도(viscosity)를 변화시켜 성대 진동을 방 해하게 되고, 또 성대의 불완전 접촉을 일으켜 음성을 변화 시킨다. 성대 반흔 조직에 대해서는 연구자에 따라 약간의 차 이는 있지만, 대게 제1형 콜라겐이 증가하고 엘라스틴(elastin) 과 히알루론산(hyaluronic acid)이 감소하는 것으로 알려져 있으며, 이러한 조성의 변화가 성대 고유의 점탄성의 변화를 유발하는 것으로 알려져 있다. ${ }^{4-8)}$

\section{현재의 성대 반흔 치료}

성대 반흔조직을 치료하기 위한 시도는 많이 이루어지고 있 다. 우선 임상에서는 가장 먼저 시행할 수 있는 것이 음성치료 이다. 음성치료는 환자의 음성 위생을 개선하여 반흔조직에 더 이상의 손상을 방지하기 위해서 사용된다. ${ }^{2}$ 그러나, 몇몇 연 구는 환자에게 맞는 음성치료가 환자의 음성의 질 향상에 실 질적인 도움이 된다고 보고한다. ${ }^{9}$ 공명음성치료(the LessacMadsen approach)는 발성 시 성대 진동과 호흡을 최소화하 면서도 맑고 뚜렷한 소리를 만들 수 있으며, 준폐색발성 훈련 (lip trills, humming, straw phonation)은 과기능성 음성장애 의 치료에서도 쓰이지만, 공명음성치료와 같이 성대 충격을 최소화하면서도 음성을 생성하는 데 도움을 준다. ${ }^{10)}$

반흔 조직으로 인한 성대의 불완전 접촉을 해결하기 위해 근막(fascia) 또는 지방(fat), 콜라겐 등 여러 물질을 주입하거 나 또는 제1형 갑상연골 성형술이 시행되고 있으나 결과는 아 주 만족스럽지 못했다. 이유는 세포외간질의 조성이 정상으로 바뀌지 않아 성대의 점탄성이 이전과 같기 때문이다.

따라서, 성대의 세포외간질을 회복하기 위하여 조직 공학적 접근이 이루어지고 있으며, 여기에는 세포치료, 이식 가능한 생체물질의 개발, 성장인자 치료 등이 포함된다. 성대 재생의 연구에서 일반적으로 생각해야 할 것은 Table 1에 정리하였다.
Table 1. General consideration about vocal fold regeneration

Animal

Species or size (mouse-human)

Age

Genetic controlled

Immune controlled

Injury

Injury method

Range or depth

Implant material

Time

Acute-chronic

Kinds

Cells (autologous-xenograft)

Scaffold or carrier

Growth factor

Implant method

Evaluation

Protein or gene expression

Macroscopic evaluation

Histology evaluation

Toxicity or immune response

Physical property

Function

\section{세포치료}

세포치료는 이비인후과 의사가 가장 쉽게 접근할 수 있는 방법이다. 세포치료는 상처 혹은 반흔이 있는 성대에 세포를 이식하여, 성대를 재생시킬 수 있다는 개념으로 여기에 사용 되는 세포에는 다양한 종류의 줄기세포(stem cell), 섬유아세 포(fibroblast), 근육아세포 등이 있다. 성대 조직에서 줄기세포 치료는 Kanemaru 등1ㅣㅇㅣ 처음 보고 하였는데, 개의 자가 골 수 줄기세포를 상처 난 성대에 주입하고 효과가 있다고 하였 다. 이후 de Bonnecaze 등른 지방조직에서 유래된 줄기세 포를 사용하여 연구하였다. 또 Hiwatashi 등 ${ }^{13)}$ 은 지방조직 유래 줄기세포와 골수 줄기세포를 비교하여 발표하기도 하였 다. 배아 줄기세포(human embryonic stem cell)와 유도 만능 줄기세포(induced pluripotent stem cells)도 사용되고 있다. ${ }^{14,15)}$

위와 같이 성대 조직 이외의 줄기세포를 이식하는 경우도 있지만, 성대조직 내에 있는 줄기세포 혹은 줄기세포처럼 분 화될 수 있고 또 줄기세포와 같은 세포 표면 항원을 가지는 섬유아세포를 활성화하는 연구도 진행되고 있다. 성대의 황 반(maculae flava)에 중간엽 줄기세포가 존재하다는 근거가 증가하면서, 이를 이용하는 연구가 진행되고 있다. ${ }^{16,17)}$

현재, 성대 재생에 있어 세포치료는 분명 도움이 되지만 그 기전은 명확히 밝혀지지 않았다. 몇몇 연구에서는 이식된 줄 
기세포가 분화(differentiation), 생착(engraftment)되어 치료 효과를 나타낸다고 하였지만, ${ }^{11,18)}$ 다른 연구에서는 이식된 줄 기세포는 4주 내에 소실되는 것으로 보여, 줄기세포 이식으 로 인한 성대 재생 효과가 이식된 줄기세포의 분화, 생착으로 인한 것이라기보다, 성대 손상 초기에 줄기세포가 분비하는 물질(secretome)의 작용으로 인한 것이라는 보고도 있다. ${ }^{13,19)}$ 줄기세포의 생존 기간과 관련하여 생각해 보아야 하는 것은, 이식된 줄기세포가 자가(autologous) 혹은 동종(allogenic) 또 는 이종(xenograft) 인지에 따라 생존 기간에 차이가 있으며, 또 이종과 동종을 사용한 경우 숙주(host)의 면역 조절 유무 에 의해서도 달라진다는 것이다. 즉, 줄기세포가 저면역성 (hypoimmunogenity)과 면역조절(immune-modulatory) 능 력을 가지고 있지만, 숙주의 면역 조절 유무에 따라 이식된 줄기세포의 생존이 달라질 수 있다는 것이다. ${ }^{20)}$ 또 줄기세포 의 생존 기간은 성대의 재생 효과와 관련이 있기에 효과적으 로 줄기세포를 이식하는 연구도 진행되었다. Amer 등 ${ }^{21}$ 은 주 입 시 발생하는 전단응력(shear stress)이 줄기세포의 생존을 감소시킬 수 있기 때문에, 식염수 기반의 전달자보다 점성이 있는 전달자가 줄기세포의 생존에 효과적이라고 보고하였다. Choi 등 ${ }^{22)}$ 은 여러 성장인자 혹은 사이토카인을 포함하는 젤 형태의 전달자를 줄기세포와 같이 이식 함으로써 줄기세포의 생존 기간을 연장하고, 생착에도 효과적이라고 보고하였다.

줄기세포의 분비작용에 기반한 재생의 개념은 세포이식 한 계 즉, 비용, 세포처리, 면역반응, 악성화 등을 극복할 수 있다 는 점에서 다른 분야에서 활발히 이루어지고 있지만, 아직 성 대 재생 분야에서는 이루어지고 있지 않다. ${ }^{23-25)}$ 많은 관심과 연구가 필요하다.

\section{이식 가능한 생체물질}

손상된 성대는 정상 성대와는 다른 조성의 세포외간질을 보 인다. 성대 재생의 초기 치료개념은 정상 세포외간질과 비교 하여 부족한 물질을 보충하는 방식으로 이루어졌으며, 그 대 표적인 물질이 히알루론산이다.

히알루론산은 음성 전하를 띠는 선형의 글리코 아미노 글 리칸으로, 고유층의 총 단백질에서 $6.4 \mu \mathrm{g} / \mathrm{mg}$ 의 농도로 분포 한다. ${ }^{26)}$ 히알루론산은 성대가 진동할 때 발생하는 충격을 흡 수하며 성대의 모양을 유지하고 특징적인 점탄성을 유지하 는 데 중요한 역할을 한다. ${ }^{27-29)}$ 체내에 존재하는 히알루론산은 분해효소(hyaluronidase)에 의해 3 5일에 분해 된다. ${ }^{30)}$ 손상된 성대에서 히알루론산 분해효소 억제하는 물질(echinacea)을 사용하여 히알루론산을 증가시키는 연구도 이루어졌으나 결 과는 아주 만족스럽지 못했다. ${ }^{31)}$ 대신 화학적으로 변형된(divi- nyl sulfone crosslink) 물질이 개발되었으며(Hylan-B), 유지 기간이 비교적 길어 성대 주입술에 사용되었으나 현재는 더 이상 생산되고 있지 않다. ${ }^{32)}$ Carbylan-GSX 또는 extracel은 부착된 gelatin의 농도 조절로 점탄성을 조절할 수 있고, 세 포와 동시에 주입 시 세포부착 능력도 향상되어 이를 이용한 동물실험이 활발하게 이루어지고 있다. ${ }^{33)}$

히알루론산에 기초한 생체물질은 단독으로도 사용되지만, 여러 종류의 줄기세포 또는 성대 섬유아세포와 같이 이식하 는 경우 성대 재생에 더욱 효과적이라고 보고하고 있다. ${ }^{34-37)}$

\section{합성물질}

성대 고유층과 같은 점탄성을 가지는 물질은 아직 개발되어 있지 않다. 따라서 아직 까지 합성물질은 성대 고유층이 아 닌 근육이나 그 아래 구조에 주입하여 성대 반흔으로 생긴 성 문 틈을 치료할 목적으로 사용된다. 이상적인 이식물은, 생체 적합성을 나타내고, 또 이식물의 물리적 성질(점탄성, 공극 율, 밀도, 미세구조 및 기계적 강도 등)과 이식물의 분해가 조 절 가능해야 한다. Polyethylene glycol(PEG)-based hyrpgel (PEG30), polycaprolactone과 pluronic F127 gel 등 FDA 승인을 얻은 물질을 이용하여 기존의 성대 주입술에 사용되 는 물질들을 대체할 수 있는 연구가 이루어졌다. PEG30은 성대의 고유층과 비슷한 점탄성을 보이고 동물실험에서 염 증과 섬유화가 거의 없어 히알루론산 기반 물질의 대체제로 보고 되었으며, pluronic F127은 성대 주입 후 부피 변화가 거의 없어 영구적 성대 주입술에 주로 사용되는 calcium hydroxyapatite를 대체할 수 있는 물질로 보고 되었다. ${ }^{38,39)}$

엘라스틴은 성대에서 차지하는 비중이 높고(무게를 기준으 로 9\%) 성대 점탄성에 중요한 역할을 하는 것으로 알려져 있 으나, 천연 엘라스틴은 용매가 적당치 않고, 추출이 어려우 며, 숙주 질환 전파의 위험이 있어 조직공학에서 사용이 어려 웠다. Grieshaber 등 ${ }^{40)}$ 은 elastin-mimetic hybrid polymer가 hexamethylene diisocyanate와 결합한 경우 천연 엘라스틴 과 유사한 탄성률을 가진 젤을 형성할 수 있으며, 섬유아세포 의 성장에 유해한 효과를 보이지 않는다고 보고하였다. 이후 엘라스틴과 비슷한 물성을 가진 합성물질에 대한 연구가 많 이 진행되고 있지만, 앞서 언급한 것처럼, 합성에 여러 단계가 필요하고, 재료의 물성을 변화시키기가 어려워 사용에 제한 이 되고 있다.

\section{성장인자}

정상 성대조직에서도 항상성 유지를 위해서 여러 성장인자 
가 분비된다. 그러나 손상 받은 성대에서는 상처 치료를 위해 성장인자의 분비에 변화가 생기게 된다. 여기서 성대의 반흔 형성을 억제하는 방향으로 유도하기 위해, 또 이미 형성된 반 흔에서는 세포외간질의 조성 변화를 유도하기 위해 다양한 종류의 성장인자가 사용된다. 대표적인 성장인자로는 간세포 성장인자(hepatocyte growth factor, HGF), 섬유아세포 성 장인자(fibroblast growth factor, FGF), 형질전환 성장인자 (transforming growth factor, TGF) 등이 있다.

간세포 성장인자는 강력한 항섬유효과, 혈관과 조직생성 특성을 가진 물질로 알려져 있으며, 줄기세포, 섬유아세포뿐 아니라 여러 곳에서 생성된다. 동물 실험을 통하여 신장, 간, 폐의 섬유화 질환에 대한 효과가 입증되었다. 성대에서도 간 세포 성장인자 수용기(HGF receptor)가 존재하며 또, 간세포 성장인자가 생성된다. 간세포 성장인자의 성대 주입은 성대 의 섬유아세포를 통한 히알루론산 합성 효소와 금속 단백분 해 효소(metalloproteinase)를 증가시키고, 이에 따라 조직 내 히알루론산의 증가와 콜라겐의 감소를 일으켜 성대 재생에 유리한 방향으로 유도한다. ${ }^{41)}$ 이런 연구를 바탕으로 Hirano 등 ${ }^{42)}$ 은 성대 반흔과 성대 구증 환자 18 명을 대상으로 인간 간 세포 성장인자 $(\mathrm{hHGF})$ 를 주입하는 임상시험을 진행하였고 주관적 음성 평가 즉, 음성장애 지수(voice handicap index-10, VHI-10)와 청지각적 음성평가(grade, rough, breathy, asthenic, strained, GRBAS scale)에서 이식 전과 비교하여 향상된 결과를 보고 하였다. 그러나 전달자를 사용하지 않아 일주일 에 1 번 환자의 성대에 직접 주입하여야 했다. 조직 공학의 발 달로 간세포 성장인자를 조직 내에서 일정기간 동안 일정 농 도로 유지(controlled release)할 수 있는 물질이 개발되고 있 지만 아직 임상에 적용하기에는 더 많은 연구가 필요하다. ${ }^{43,44)}$

섬유아세포 성장인자(FGF) 역시 성대의 재생에 자주 이 용되며 많은 연구가 이루어졌다. 섬유아세포 성장인자는 히 알루론산 messenger ribonucleic acid(mRNA)의 발현을 증 가시키고 제 1 형 콜라겐의 mRNA 발현을 감소시켜 세포외간 질을 정상화하는데 도움이 된다고 보고되고 있으며, Hirano 등 ${ }^{45}$ 과 Kanazawa 등 ${ }^{46}$ 에 의해 임상연구에 대한 보고도 이루 어졌다. Hirano 등 ${ }^{45)}$ 은 성대 반흔에 섬유아세포 성장인자를 1 주일 간격으로 4번 주입한 군과 반흔 제거 수술 후 섬유아세 포 성장인자를 젤라틴과 같이 주입한 군을 비교하였고, 두 군 모두 시술 3개월 후 음성장애 지수(VHI-10)와 GRBAS scale 에서 유의한 효과가 있다고 보고하였다. Kanazawa 등은 Hirano 등이 사용한 것보다 5 배 높은 농도의 섬유아세포 성장 인자를 성대의 양측에 1 번 주입하였고, 음성장애 지수(VHI) 와 음향분석에서 효과가 있다고 보고하였다. 그러나 두 연구 모두 대상 환자가 균일하지 못하고(성대 마비, 성대 구증, 성대
반흔, 노인 성대) 대상자의 수가 적어 질환 별로 많은 환자를 대상으로 하는 연구가 필요하다.

베타 1형 형질전환 성장인자(TGF- $\beta 1)$ 는 profibrotic mediator로 조직의 섬유화에 중요한 역할을 한다. 조직의 섬유 화는 상처 회복과정에서 꼭 필요하지만 지나친 섬유화는 기능 적 문제를 일으킨다. 따라서 상처 치유과정에서 나타나는 베 타 1형 형질전환 성장인자의 상향조절(up-regulation)을 통제 하고자 하는 실험이 이루어졌으며, 최근에는 3형 스마드 단백 질(SMAD3) 발현이 베타 1형 형질전환 성장인자로 유발되는 조직 섬유화의 시그널에 관련 있음이 보고 되었고 이에 3형 스마드 단백질을 통제함으로써 조직의 섬유화를 줄이려는 연구가 활발히 이루어지고 있다. ${ }^{47,48)}$

\section{재생의 평가}

동물 실험에서 재생의 효과는, 대개 유전자 혹은 단백질의 발현과 이에 따른 형태학적인 평가(내시경과 조직 슬라이드) 그리고 재생된 조직의 기능적 평가로 이루어진다.

재생과정에 나타나는 mRNA의 발현과 이에 따른 단백질 의 차이는 상처 회복의 급성기에는 매우 변동이 심하기 때문 에, 분석하고자 하는 유전자나 단백질의 발현은 시간 간격을 가지고 최소 2 회 이상 분석하는 것이 유의미한 변화를 관찰 하는 데 도움이 된다.

급성기의 유전자 발현 혹은 단백질의 차이가 조직의 형태 에 변화를 유도하는지 여부는 내시경과 조직 염색으로 평가 하게 된다. 성대의 거시적 형태(반흔의 정도, 육아종 생성 여부 등)는 내시경이나 수술용 현미경을 통하여 평가할 수 있으며, 재생된 성대의 미시적 형태는 조직 염색을 통하여 평가된다. 일반적으로 조직의 콜라겐, 탄성섬유의 침착 양과 침착 형태 를 관찰하고, 히알루론산의 농도와 분포도 관찰한다. 또 시 험과정에서 사용된 줄기세포, 성장인자, 전달자도 면역 염색 을 통하여 확인할 수 있다. 이종 혹은 동종의 세포를 사용한 경우, 거부반응 여부도 살펴보는 것이 중요하다.

성대 기능은 음성을 생성하는 것이므로, 사람의 경우 음성 검사나 음향학적 분석을 통하여 기능을 평가할 수 있으나, 동물 실험에 주로 이용되는 쥐나 토끼의 경우는 음향학적 분 석이 불가능하다. 따라서 재생된 성대의 물성, 즉 점탄성 계 수를 정상과 비교 하거나, 초고속 카메라를 이용하여 성대의 파동과 성대의 간격을 관찰함으로써 간접적으로 기능을 평 가할 수 있다. 


\section{동물 실험의 한계}

성대 재생의 실험은 성대의 손상을 가하거나 혹은 반흔 조 직을 만든 상태에서 실험이 이루어지고 또 평가가 된다. 그러 나 아직까지 균일하게 성대 손상을 일으키는 기구와 매뉴얼 이 없다. 즉 연구자에 따라 손상 정도와 방법이 다르고, 또 동일 연구에서도 여러 개체에 동일한 손상을 만들 수 없다. 실험 개체 수를 늘려 오차를 줄일 수 있지만, 시간과 노력, 비 용이 만만하지 않다. 신뢰할 수 있는 성대 손상의 기술에 대 한 연구가 필요하다.

\section{결 론}

성대 재생의 정확한 기전은 밝혀지지 않았다. 그러나, 현재 까지 알려진 기전과 이를 효과적으로 구현하기 위한 노력이 진 행되고 있다. 여기 생체 적합한 합성물질을 포함하는 이식물 질개발, 세포, 성장인자의 이식과 이들 간의 조합으로 인한 시 너지 효과를 포함한다. 생체물질의 개발과 또는 이미 개발된 물질을 응용하고 사용하기 위해서는 다학제의 협업이 필요하 다. 또 현재의 연구는 대부분 반흔 생성을 억제하는 부분에 초점이 맞춰 있지만, 성대 재생 기전에 대하여 활발한 연구가 이루어진다면 생성된 반흔에 대한 치료도 효과적으로 이루 어질 것으로 생각된다.

\section{REFERENCES}

1) Suzuki R, Kawai Y, Tsuji T, Hiwatashi N, Kishimoto Y, Tateya I, et al. Prevention of vocal fold scarring by local application of basic fibroblast growth factor in a rat vocal fold injury model. Laryngoscope 2017; 127(2):E67-E74.

2) Benninger MS, Alessi D, Archer S, Bastian R, Ford C, Koufman J, et al. Vocal fold scarring: current concepts and management. Otolaryngol Head Neck Surg 1996;115(5):474-82.

3) Catten M, Gray SD, Hammond TH, Zhou R, Hammond E. Analysis of cellular location and concentration in vocal fold lamina propria. Otolaryngol Head Neck Surg 1998;118(5):663-7.

4) Rousseau B, Hirano S, Chan RW, Welham NV, Thibeault SL, Ford $\mathrm{CN}$, et al. Characterization of chronic vocal fold scarring in a rabbit model. J Voice 2004;18(1):116-24.

5) Hirano $S$, Minamiguchi $S$, Yamashita M, Ohno T, Kanemaru $S$, Kitamura M. Histologic characterization of human scarred vocal folds. J Voice 2009;23(4):399-407.

6) Thibeault SL, Gray SD, Bless DM, Chan RW, Ford CN. Histologic and rheologic characterization of vocal fold scarring. J Voice 2002; 16(1):96-104.

7) Hirano S, Bless DM, Rousseau B, Welham N, Scheidt T, Ford CN. Fibronectin and adhesion molecules on canine scarred vocal folds. Laryngoscope 2003;113(6):966-72.

8) Tateya T, Tateya I, Sohn JH, Bless DM. Histologic characterization of rat vocal fold scarring. Ann Otol Rhinol Laryngol 2005;114(3): 183-91.

9) Speyer R, Wieneke GH, van Wijck-Warnaar I, Dejonckere PH. Effects of voice therapy on the voice range profiles of dysphonic patients. J
Voice 2003;17(4):544-56.

10) Titze IR. Voice training and therapy with a semi-occluded vocal tract: rationale and scientific underpinnings. J Speech Lang Hear Res 2006;49(2):448-59.

11) Kanemaru S, Nakamura $T$, Omori $K$, Kojima H, Magrufov A, Hiratsuka Y, et al. Regeneration of the vocal fold using autologous mesenchymal stem cells. Ann Otol Rhinol Laryngol 2003;112(11): 915-20.

12) de Bonnecaze G, Chaput B, Woisard V, Uro-Coste E, Swider P, Vergez S, et al. Adipose stromal cells improve healing of vocal fold scar: Morphological and functional evidences. Laryngoscope 2016; 126(8):E278-E85.

13) Hiwatashi N, Hirano S, Mizuta M, Tateya I, Kanemaru S, Nakamura $\mathrm{T}$, et al. Adipose-derived stem cells versus bone marrow-derived stem cells for vocal fold regeneration. Laryngoscope 2014;124(12): E461-E9.

14) Cedervall J, Ahrlund-Richter L, Svensson B, Forsgren K, Maurer $\mathrm{FH}$, Vidovska D, et al. Injection of embryonic stem cells into scarred rabbit vocal folds enhances healing and improves viscoelasticity: short-term results. Laryngoscope 2007;117(11):2075-81.

15) Imaizumi M, Sato Y, Yang DT, Thibeault SL. In vitro epithelial differentiation of human induced pluripotent stem cells for vocal fold tissue engineering. Ann Otol Rhinol Laryngol 2013;122(12): 737-47.

16) Sato $K$, Umeno $H$, Nakashima $T$. Vocal fold stem cells and their niche in the human vocal fold. Ann Otol Rhinol Laryngol 2012;121(12): 798-803.

17) Kurita T, Sato K, Chitose S, Fukahori M, Sueyoshi S, Umeno H. Origin of vocal fold stellate cells in the human macula flava. Ann Otol Rhinol Laryngol 2015;124(9):698-705.

18) Kanemaru $S$, Nakamura $T$, Yamashita $M$, Magrufov $A$, Kita $T$, Tamaki $\mathrm{H}$, et al. Destiny of autologous bone marrow-derived stromal cells implanted in the vocal fold. Ann Otol Rhinol Laryngol 2005;114 (12):907-12.

19) Kim CS, Choi H, Park KC, Kim SW, Sun DI. The ability of human nasal inferior turbinate-derived mesenchymal stem cells to repair vocal fold injuries. Otolaryngol Head Neck Surg 2018 Mar 1 [Epub ahead of print]. www.dx.doi.org/10.1177/0194599818764627.

20) Morisaki T, Kishimoto Y, Tateya I, Kawai Y, Suzuki R, Tsuji T, et al. Adipose-derived mesenchymal stromal cells prevented rat vocal fold scarring. Laryngoscope 2018;128(1):E33-E40.

21) Amer MH, Rose FRAJ, Shakesheff KM, White LJ. A biomaterials approach to influence stem cell fate in injectable cell-based therapies. Stem Cell Res Ther 2018;9(1):39.

22) Choi JW, Park JK, Chang JW, Kim DY, Kim MS, Shin YS, et al. Small intestine submucosa and mesenchymal stem cells composite gel for scarless vocal fold regeneration. Biomaterials 2014;35(18):4911-8.

23) Baglio SR, Pegtel DM, Baldini N. Mesenchymal stem cell secreted vesicles provide novel opportunities in (stem) cell-free therapy. Front Physiol 2012;3:359.

24) Lee SK, Lee SC, Kim SJ. A novel cell-free strategy for promoting mouse liver regeneration: utilization of a conditioned medium from adipose-derived stem cells. Hepatol Int 2015;9(2):310-20.

25) Muhammad SA, Nordin N, Fakurazi S. Regenerative potential of secretome from dental stem cells: a systematic review of preclinical studies. Rev Neurosci 2018;29(3):321-32.

26) Hahn MS, Kobler JB, Starcher BC, Zeitels SM, Langer R. Quantitative and comparative studies of the vocal fold extracellular matrix. I: elastic fibers and hyaluronic acid. Ann Otol Rhinol Laryngol 2006; 115(2):156-64.

27) Gaston J, Thibeault SL. Hyaluronic acid hydrogels for vocal fold wound healing. Biomatter 2013 Jan-Mar [Epub ahead of print]. www. dx.doi.org/10.4161/biom.23799.

28) Chan RW, Gray SD, Titze IR. The importance of hyaluronic acid in 
vocal fold biomechanics. Otolaryngol Head Neck Surg 2001;124 (6):607-14.

29) Butler JE, Hammond TH, Gray SD. Gender-related differences of hyaluronic acid distribution in the human vocal fold. Laryngoscope 2001;111(5):907-11.

30) Fraser JR, Laurent TC, Laurent UB. Hyaluronan: its nature, distribution, functions and turnover. J Intern Med 1997;242(1):27-33.

31) Rousseau B, Tateya I, Lim X, Munoz-del-Rio A, Bless DM. Investigation of anti-hyaluronidase treatment on vocal fold wound healing. J Voice 2006;20(3):443-51.

32) Hallén L, Johansson C, Laurent C. Cross-linked hyaluronan (Hylan B gel): a new injectable remedy for treatment of vocal fold insufficiency-an animal study. Acta Otolaryngol 1999;119(1):107-11.

33) Kazemirad S, Heris HK, Mongeau L. Viscoelasticity of hyaluronic acid-gelatin hydrogels for vocal fold tissue engineering. J Biomed Mater Res B Appl Biomater 2016;104(2):283-90.

34) Johnson BQ, Fox R, Chen $X$, Thibeault $S$. Tissue regeneration of the vocal fold using bone marrow mesenchymal stem cells and synthetic extracellular matrix injections in rats. Laryngoscope 2010;120(3): $537-45$.

35) Duflo S, Thibeault SL, Li W, Shu XZ, Prestwich G. Effect of a synthetic extracellular matrix on vocal fold lamina propria gene expression in early wound healing. Tissue Eng 2006;12(11):3201-7.

36) Heris HK, Daoud J, Sheibani S, Vali H, Tabrizian M, Mongeau L. Investigation of the viability, adhesion, and migration of human fibroblasts in a hyaluronic acid/gelatin microgel-reinforced composite hydrogel for vocal fold tissue regeneration. Adv Healthc Mater 2016; 5(2):255-65.

37) Kim YM, Oh SH, Choi JS, Lee S, Ra JC, Lee JH, et al. Adipose-derived stem cell-containing hyaluronic acid/alginate hydrogel improves vocal fold wound healing. Laryngoscope 2014;124(3):E64-E72.

38) Kwon SK, Song JJ, Cho CG, Park SW, Choi SJ, Oh SH, et al. Polycaprolactone spheres and theromosensitive Pluronic F127 hydrogel for vocal fold augmentation: in vivo animal study for the treatment of unilateral vocal fold palsy. Laryngoscope 2013;123(7): 1694-703.

39) Karajanagi SS, Lopez-Guerra G, Park H, Kobler JB, Galindo M,
Aanestad J, et al. Assessment of canine vocal fold function after injection of a new biomaterial designed to treat phonatory mucosal scarring. Ann Otol Rhinol Laryngol 2011;120(3):175-84.

40) Grieshaber SE, Farran AJ, Lin-Gibson S, Kiick KL, Jia X. Synthesis and characterization of elastin-mimetic hybrid polymers with multiblock, alternating molecular architecture and elastomeric properties. Macromolecules 2009;42(7):2532-41.

41) Ohno T, Hirano S, Rousseau B. Gene expression of transforming growth factor-betal and hepatocyte growth factor during wound healing of injured rat vocal fold. Laryngoscope 2009;119(4):806-10.

42) Hirano S, Kawamoto A, Tateya I, Mizuta M, Kishimoto Y, Hiwatashi $\mathrm{N}$, et al. A phase I/II exploratory clinical trial for intracordal injection of recombinant hepatocyte growth factor for vocal fold scar and sulcus. J Tissue Eng Regen Med 2018;12(4):1031-8.

43) Choi JW, Kim YS, Park JK, Song EH, Park JH, Kim MS, et al. Controlled release of hepatocyte growth factor from MPEG-b(PCL-ran-PLLA) diblock copolymer for improved vocal fold regeneration. Macromol Biosci 2017 Feb [Epub ahead of print]. www.dx.doi.org/10.1002/mabi.201600163.

44) Choi JS, Lee S, Kim DY, Kim YM, Kim MS, Lim JY. Functional remodeling after vocal fold injury by small intestinal submucosa gel containing hepatocyte growth factor. Biomaterials 2015;40:98-106.

45) Hirano S, Mizuta M, Kaneko M, Tateya I, Kanemaru S, Ito J. Regenerative phonosurgical treatments for vocal fold scar and sulcus with basic fibroblast growth factor. Laryngoscope 2013;123(11):274955 .

46) Kanazawa T, Komazawa D, Indo K, Akagi Y, Lee Y, Nakamura K, et al. Single injection of basic fibroblast growth factor to treat severe vocal fold lesions and vocal fold paralysis. Laryngoscope 2015;125 (10):E338-E44.

47) Hiwatashi N, Benedict PA, Dion GR, Bing R, Kraja I, Amin MR, et al. SMAD3 expression and regulation of fibroplasia in vocal fold injury. Laryngoscope 2017;127(9):E308-E16.

48) Paul BC, Rafii BY, Gandonu S, Bing R, Born H, Amin MR, et al. Smad3: an emerging target for vocal fold fibrosis. Laryngoscope 2014;124(10):2327-31.

\section{정답 및 해설}

1. 답 (3) 방선균증(actinomycosis). 이비인후과학 두경부외과학 교과서. 서울: 일조각;2009. p.1748.

해 설 (1) 그람양성 비항산균 호기성 세균이다. (2) 수술적 치료는 항생제에 반응하지 않는 경우나, 비강내 질환, 방사선골 괴사 가 있는 경우, 괴사조직 및 섬유조직의 제거가 필요한 경우에 시행한다. (4) 경부안면형, 복부형, 흉부형 3가지 임상형 중 경부안면형이 가장 흔하다. (5) 치료에 사용되는 항생제로는 penicillin이 가장 좋은 항생제로 알려져 있다. 